\title{
THE RELATIONSHIP BETWEEN MICROFINANCE AND TOURISM (CASE OF ALBANIA)
}

\author{
Forcim Kola ${ }^{1}$ \\ Bardhyl Ceku ${ }^{2}$ \\ Semiha Loca ${ }^{3}$
}

DOI: https://doi.org/10.31410/LIMEN.2019.165

\begin{abstract}
The purpose of this paper is to analyse the link between microfinance and tourism, explaining how microfinance institutions (MFIs) in Albania are supporting the development of tourism through providing microcredit to small tourism enterprises.

Microfinance can offer low income people specifically those called un-bankable, the necessary financial support to enter entrepreneurship activities in tourism sector. On the other side, tourism development can contribute to reduce poverty through economic development especially in rural and mountainous areas.

Primary data are used to show a descriptive panorama of the two main variables and a casual analysis is done through secondary data on tourism and microcredit sector in Albania.
\end{abstract}

Using a Linear Regression Analysis, it is evidenced a relationship between the two analysed variables.

Keywords: Microfinance, Microcredit, Tourism, Linear regression.

\section{INTRODUCTION}

$\mathrm{A}^{\mathrm{l}}$ lbania has made remarkable economic progress during the past three decades. Due to the strong growth performance, Albania grew from one of the poorest nations in Europe to a middle-income country, with poverty declining by half during that period.

However, Albania's growth model needs to shift from consumption-fuelled to investment- and export-led growth. The new model will need to help those people with less access to economic opportunities to contribute to, and benefit from economic growth ${ }^{4}$.

More than half of the population live in rural areas, where slightly less than one fifth of Gross Domestic Product $(G D P)$ is generated in agriculture, which, following transition, is now almost exclusively based on very small-scale and typically fragmented farming units.

The Albanian government has identified tourism as a key economic sector, touting its potential to spur development of the entire country. Located in the Mediterranean region, Albania could well represent Europe's last tourism "secret."

\footnotetext{
1 “Marin Barleti” University, Rruga Sami Frashëri 41, Tirana 1000, Albania

2 Agriculture University of Tirana, Kodër Kamëz, SH1, Tirana 1000, Albania

3 “Marin Barleti” University, Rruga Sami Frashëri 41, Tirana 1000, Albania

4 https://www.worldbank.org/en/country/albania/overview/December 2019

5 https://www.export.gov/article?id=Albania-Travel-and-Tourism/January 2020
} 


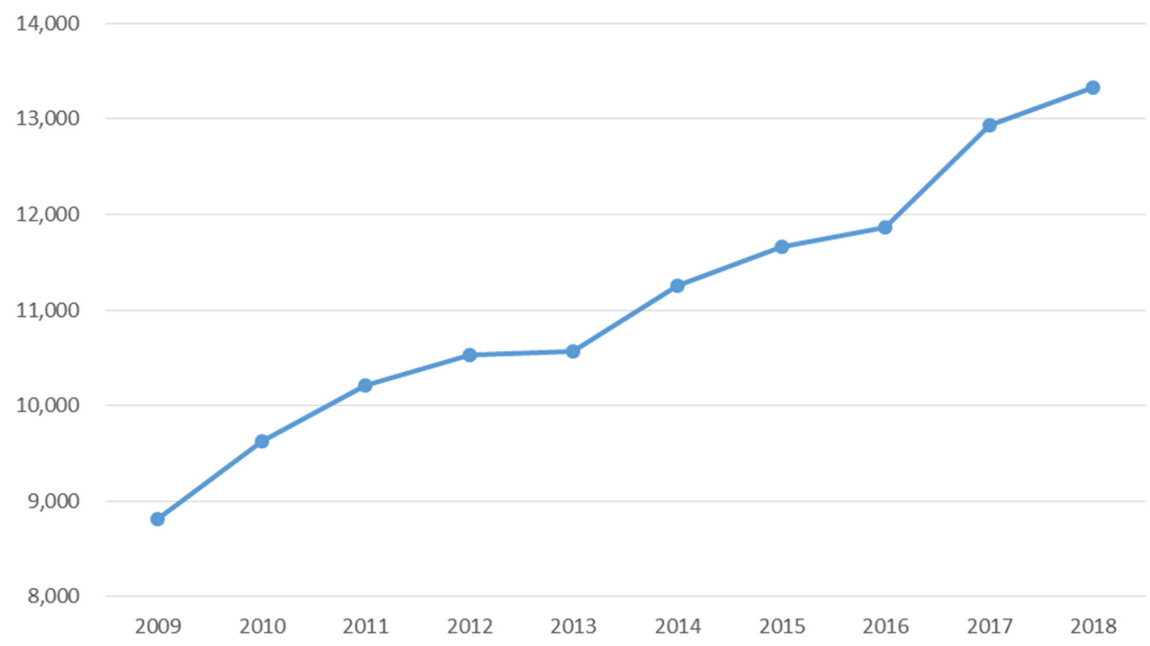

Chart 1. GDP per Capita (USD) of Albania ${ }^{6}$

Whereas tourism has been variably heralded and cursed as a solution to development, sustainable tourism, notably with a pro-poor approach, has recently begun to celebrate successes based on local participation and resources, equitable partnerships, and the maintenance of cultural and environmental integrity of a location.

Referring the GDP structure of Albania, about 50\% comes from Service, 20\% from Agriculture, same percentage from Industry and some rest from other activities (Chart 2).

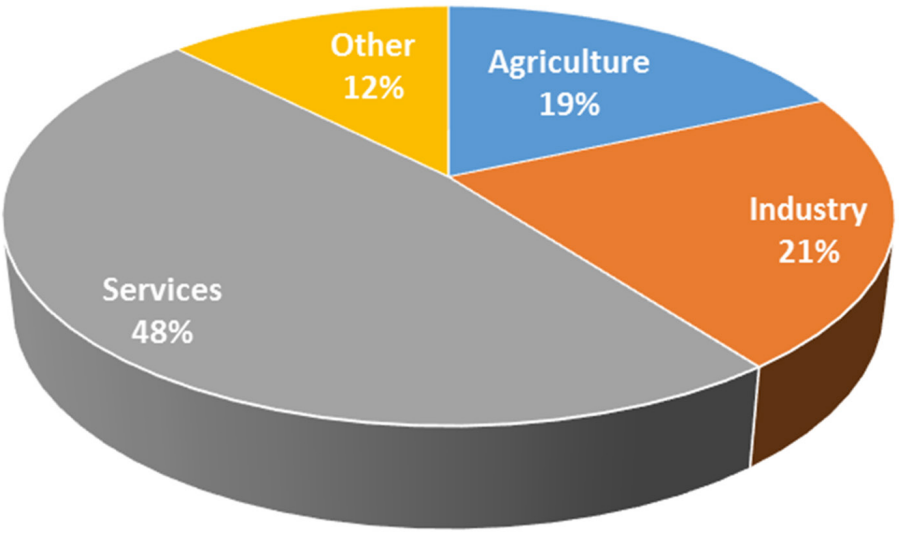

Chart 2. GDP of Albania per sectors $(2018)^{7}$

The sustainable tourism for development is suggested as an entrepreneurial, locally rooted, and locally defined solution, contributing to poverty alleviation through economic and social benefits similar to a social business.

The tourism industry is seen as a promising sector for developing countries. Evidence of successful growth through tourism in developing countries is usually given by increased numbers of international arrivals and gross tourist expenditures in hard currencies. International tourism arrivals to developing countries have increased by 6.5 per cent annually since 1988, a higher rate than average world growth of arrivals. Income through international visitors is representing a large component of international exports in the Least Developed Countries (Denman et al. 2004, WTO 2002a).

\footnotetext{
6 http://www.worldbank.org/November 2019

7 https://www.statista.com/December 2019
} 
The number of tourist arrivals to Albania reached nearly 6 million in 2018, a 15\% increase over 2017, many of whom were visitors from neighbouring countries. A growing number of U.S. citizens also visit Albania, particularly the southern coastal region, as part of day-excursions from Corfu, Greece.

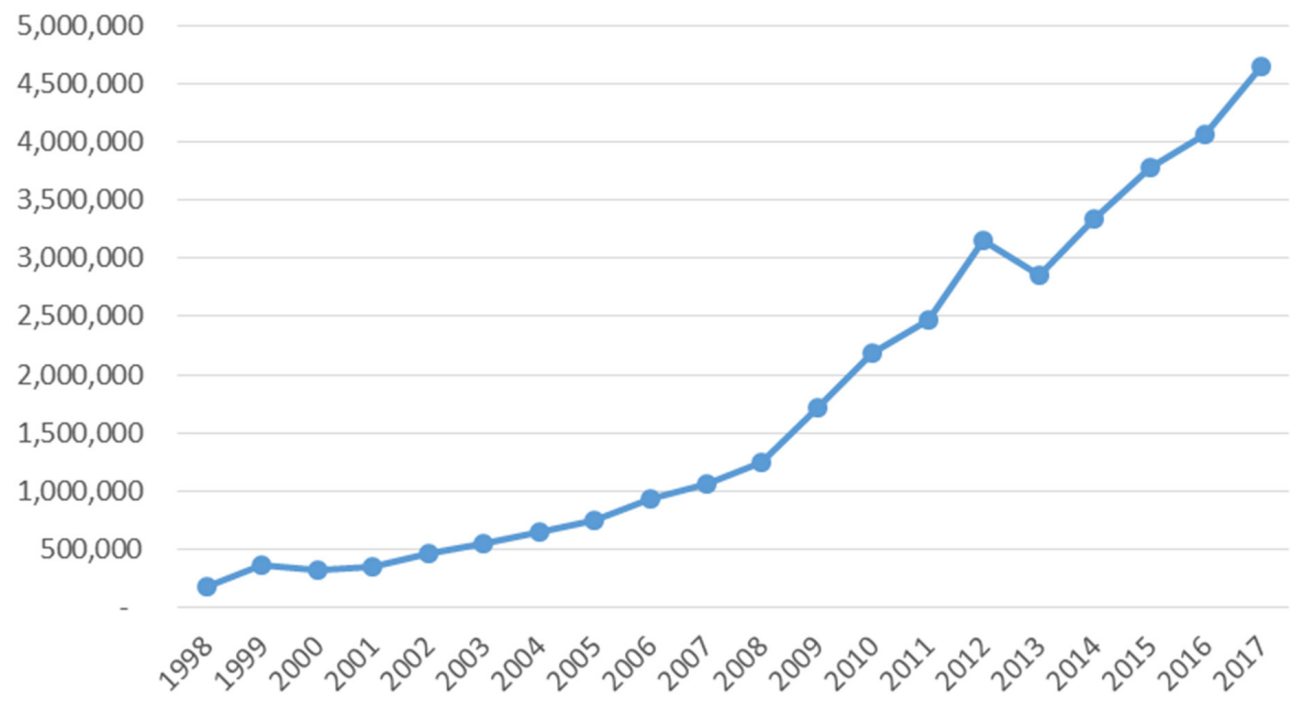

Chart 3. International tourism, number of arrivals ${ }^{8}$

According to the 2019 World Travel and Tourism Council Report on Albania, travel and tourism receipts in 2018 reached $\$ 4.27$ billion, or $27.3 \%$ of GDP. Tourism service exports generated $\$ 2.15$ billion in 2018 , or $48 \%$ of total exports 9 .

Many researchers have indicated that tourism on its own cannot be an explanation for specialised tourism countries achieving higher growth rates. It appears that faster growth rates are more related to the fact that some economies are more open and liberalized than others.

Tourism is a service industry and benefits strongly from liberalized and open economies. Also, specific factor productivity plays an important role in materializing growth, e.g. the extent to which tourism growth leads to more demand for human resources and human capital accumulation.

The liberalization of developing economies usually starts with the modernization of their domestic financial markets. There appears to be a positive relationship between open and modernized financial markets and poverty alleviation. When it comes to the relationship with poverty alleviation, the main topic is to provide poor people with access to financial services. This is mainly promoted through Microfinance Institutions (MFIs).

Microfinance can offer low income people specifically those called un-bankable, the necessary financial support to enter entrepreneurship activities in tourism sector. On the other side, tourism development can contribute to reduce poverty through economic development especially in rural and mountainous areas.

\footnotetext{
8 http://www.worldbank.org/November 2019

9 https://www.export.gov/article?id=Albania-Travel-and-Tourism/January 2020
} 


\section{ECONOMIC DEVELOPMENT AS A RESULT OF TOURISM}

Derived Tourism is a major engine for job creation and a driving force for economic growth and development, as highlighted by recent figures.

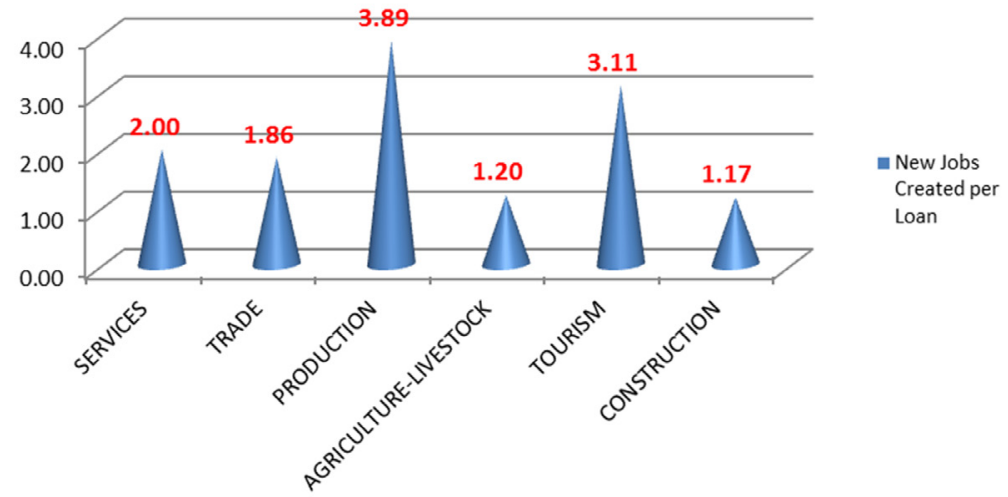

Chart 4. New jobs created per loan as per sectors supported by Microfinance Sector in Albania

According to the World Travel and Tourism Council data, in 2015 tourism directly created over 107 million jobs (3.6 per cent of total employment representing 3 per cent of total GDP) and supported (directly and indirectly) a total of 284 million jobs, equivalent to one in 11 jobs in the world. By 2026, these figures are expected to increase to 136 and 370 million jobs respectively representing one in nine of all jobs worldwide ${ }^{10}$.

If we see the figures in Albania, from every loan disbursed by MFIs in tourism sector in Albania, there were created 3,11 New Jobs (Chart 4).

These statistics highlighting the significant contribution of tourism to employment and GDP speak for themselves. Furthermore, it is essential to make sure that the growth and development of this sector is sustainable, socially responsible and creates decent work opportunities.

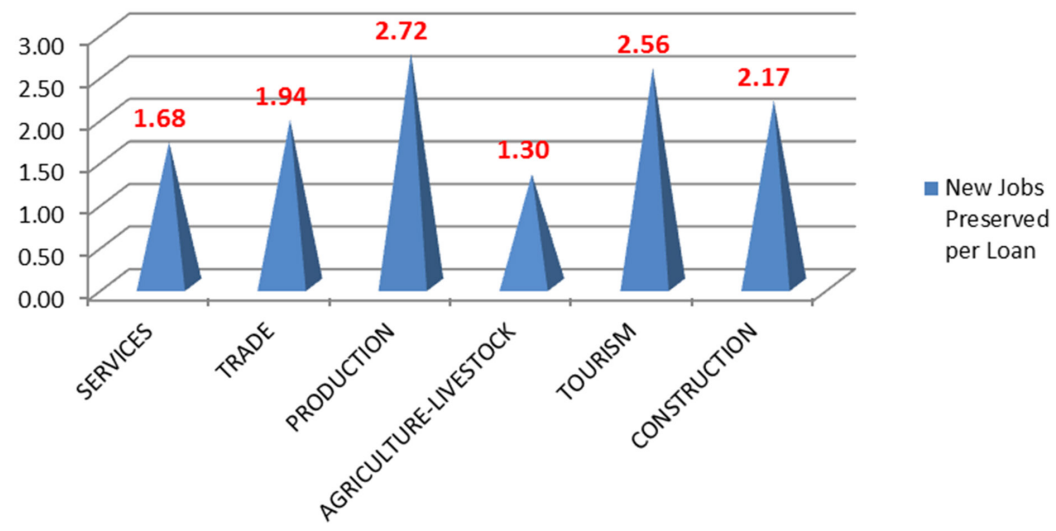

Chart 5. Number of jobs preserved per loan as per sectors supported by microfinance Sector in Albania

Also, evidences from Albania showed us that from every loan disbursed by MFIs in tourism sector in this country, there were preserved 2,56 Jobs (Chart 5).

10 https://www.ilo.org/global/about-the-ilo / January 2020 


\section{ECONOMIC DEVELOPMENT AND FINANCIAL SECTOR}

A well-functioning financial sector is one of the cornerstones of long-term economic growth in a national economy. Financial services are the "gearing oil" of an economy.

It can have positive impacts on capital accumulation and on the rate of technological progress. In order to support and stimulate economic growth in an economy, financial intermediaries like commercial banks and savings- and credit cooperatives are needed to the effect of:

- Savings mobilization,

- Provision of loans to stimulate and facilitate economic growth,

- Management of risks,

- Provision of information on investment opportunities,

- Monitoring of borrowers,

- Facilitation of exchange of goods and services.

The number of banks in Albania declined to 14 in 2018 due to the acquisition of two foreign subsidiaries in the Albanian banking system.

Compared to the banking sector, the non-bank financial institutions account for a small fraction of the financial system when measured by asset size. Currently, there are 30 non-bank financial institutions and 13 savings and credit institutions.

Despite the large number, their financial activity is relatively small. The total assets of non-bank financial institutions account for around 3.9\% of GDP as of $2018^{11}$.

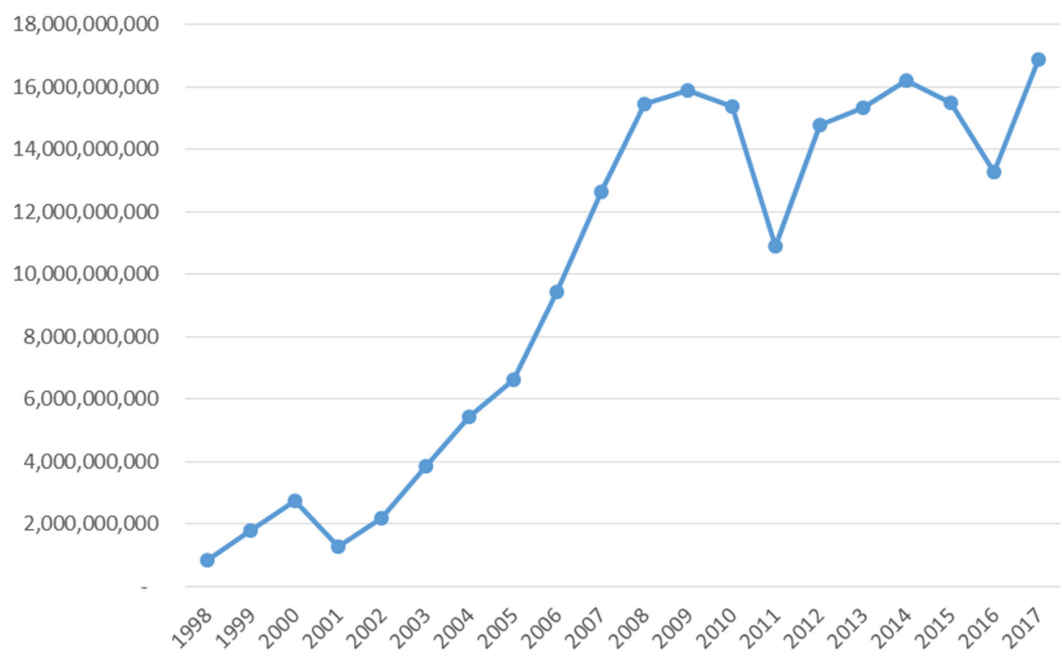

Chart 6. Gross Loan Portfolio of MFIs ${ }^{12}$

According to figures from the World Bank, we can evidence an increase in the Gross Loan Portfolio of the MFIs in Albania (Chart 6).

The trend was quite positive from 2001 to 2009 with such a big increase of the loan portfolio of MFIs, and after 2009 we still had an increase but with some changes such as in 2011 and 2016 when we evidenced small decreases.

11 https://www.ebf.eu/albania/December 2019

12 http://www.worldbank.org/November 2019 


\section{RELATIONSHIP BETWEEN MFIS PORTFOLIO AND TOURISM DEVELOPMENT}

We have taken two variables to analyse the relationship between microfinance and tourism:

$$
\begin{aligned}
& \text { X - Gross Loan Portfolio of MFIs, } \\
& \text { Y - Number of tourists entering Albania. }
\end{aligned}
$$

In order to explaining how microfinance institutions (MFIs) in Albania are supporting the development of tourism through providing microcredit to small tourism enterprises we made a Simple Linear regression between these two variables, as it is described in the chart below.

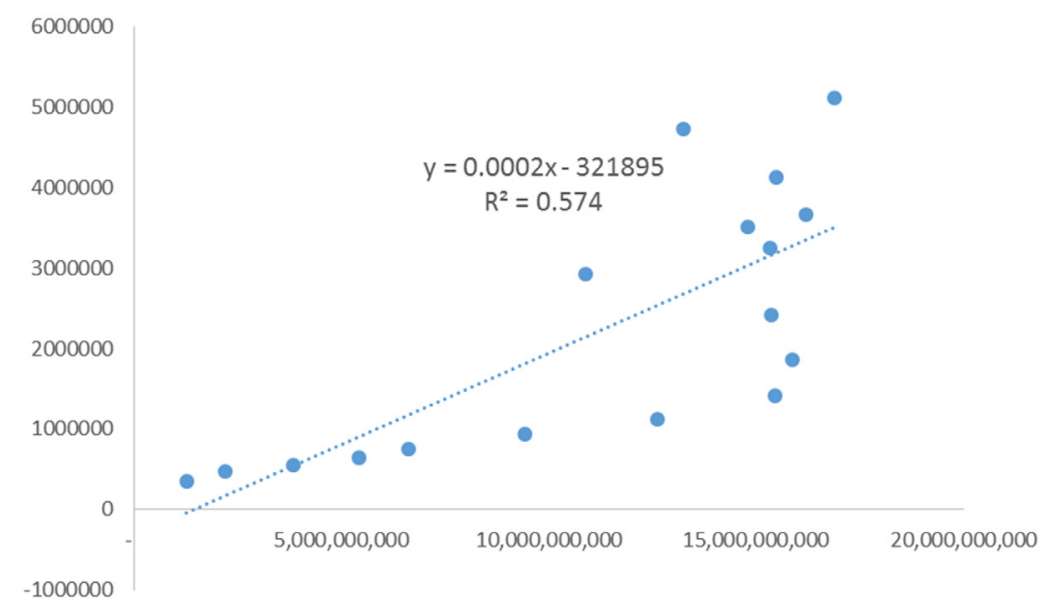

Chart 7. Number of tourists entering Albania to Portfolio of MFIs

We can see a positive relationship between number of tourists entering Albania and loan portfolio of MFIs in Albania (Chart 7). This relationship seems to be at an average level but positive, meaning the increase of the crediting by Albanian MFIs will bring more tourists in this country.

This is because as MFIs increase their portfolio, they credit more the tourism sector in Albania, supporting so the small investments in tourism sector to better perform their service and mostly to increase their capacity.

The increased capacity in tourism means bigger offer for tourists entering Albania adding also the improvements in service quality.

This in return brings job creation, more sales of related products on the whole tourism value chain and respectively economic development of the country.

\section{CONCLUSION}

Microfinance institutions (MFIs) in Albania are supporting the development of tourism through providing microcredit to small tourism enterprises.

It was evidenced that microfinance sector in Albania is creating 3,11 New Jobs and preserving 2,56 Jobs from every loan they disburse in tourism sector in this country. 
As collected data have shown, there is an average positive link between loan portfolio of Albanian MFIs and the number of tourists entering Albania during the last years.

That means extending the loan portfolio of MFIs can have a positive impact of increasing the investments and entrepreneurship in tourism sector in Albania, increasing and improving the tourism offer of the country, which in turn results in bringing more tourists to the country developing greatly the whole country's economy.

\section{REFERENCES}

Altman J.C. \& Finlayson J. (1992), “Aborigines, tourism and sustainable development”, Centre for Aboriginal Economic Policy Research (CAEPR), No.26

Ashley C. \& Roe D. (2002), "Making tourism work for the poor: strategies and challenges in southern Africa", Development Southern Africa, Vol. 19, No. 1, pp.61-82

Ashley C., De Brine P., Lehr A. \& Wilde H. (2007), "The Role of the Tourism Sector in Expanding Economic Opportunity", Economic Opportunity Series, The Fellows of Harvard College, Overseas Development Institute, International Business Leaders Forum.

Balomenou, Dr. C. K., D. Lagos, Panagyiotis J (2005).: Tourist enterprises financing in Greece.

Bannock G. (2005): The economics and management of small business, an international perspective: Routledge Taylor and Francis Group, ISBN 0-415-33666-X

Budeanu A. (2007), "Sustainable tourist behaviour - a discussion of opportunities for change",

Croes R., Rivera M. - Poverty Alleviation through Tourism Development: A Comprehensive and Integrated Approach (Advances in Hospitality and Tourism) 1st Edition, 2015

http://www.worldbank.org/November 2019

https://www.ebf.eu/albania/December 2019

https://www.export.gov/article?id=Albania-Travel-and-Tourism/January 2020

https://www.ilo.org/global/about-the-ilo / January 2020

https://www.statista.com/December 2019

Sharpley R., Telfer D. - Tourism and Development: Concepts and Issues (63) (Aspects of Tourism (63)) 2nd Edition, 2014

Yunus M. - Creating a World Without Poverty; Social Business and the Future of Capitalism, 2007 